\title{
The influence of the fasting period on the number of nymphal instars and on the sex ratio of Argas (Persicargas) miniatus (Acari: Argasidae)
}

\author{
Influência do período de jejum no número de instares ninfais \\ e na razão sexual de Argas (Persicargas) miniatus (Acari: Argasidae)
}

\author{
Huarrisson Azevedo Santos ${ }^{1 *}$; Isabele da Costa Angeloº; Marcos Pinheiro Franque²;

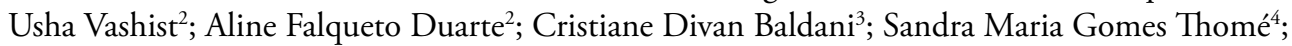 \\ João Luiz Horacio Faccini ${ }^{5}$; Carlos Luiz Massard ${ }^{5}$
}

${ }^{1}$ Curso de Pós-Graduação em Ciências Veterinárias, Universidade Federal Rural do Rio de Janeiro - UFRRJ

${ }^{2}$ Curso de Graduação em Medicina Veterinária, Universidade Federal Rural do Rio de Janeiro - UFRRJ, Bolsista CAPES

${ }^{3}$ Escola de Medicina Veterinária e Zootecnia, Universidade Federal do Tocantins - UFT

${ }^{4}$ Departamento de Epidemiologia e Saúde Pública, Instituto de Veterinária, Universidade Federal Rural do Rio de Janeiro - UFRRJ

${ }^{5}$ Departamento de Parasitologia Animal, Instituto de Veterinária, Universidade Federal Rural do Rio de Janeiro - UFRRJ

Received Mach 8, 2010

Accepted July 7, 2010

\begin{abstract}
The current study investigated the biology of nymphs of the first and second instars of Argas (Persicargas) miniatus. Nymphs were deprived of food for 15,30 or 60 days and held at $27 \pm 1{ }^{\circ} \mathrm{C}$ and $80 \pm 10 \%$ relative humidity (controlled conditions) or at room conditions of temperature and relative humidity. Nymphs of first instar deprived of food for 15 or 30 days molted to second and third instars in both controlled and room conditions. Nymphs of the first instar deprived of food for 60 days had 28 and $37 \%$ mortality in controlled and room conditions, respectively; and survivors did not attach to the host. Nymphs of the second instar, deprived of food for 60 days, molted either to the third instar or to males after feeding on Gallus gallus, and the nymphs of the third instar developed to adults $(42.42 \%$ males and $36.36 \%$ females when nymphs were held in controlled temperature and humidity conditions, and $40.54 \%$ males and $48.65 \%$ females when nymphs were held in room conditions). The remainder of the nymphs molted to the fourth instar and then molted to females. In conclusion, the nymphal starvation period of 60 days determined the number of nymph instars in the life cycle of $A$. miniatus under the experimental conditions studied.
\end{abstract}

Keywords: Argas (Persicargas) miniatus, number of nymphal instar, starvation period, argasid tick.

\section{Resumo}

Os aspectos biológicos de ninfas de primeiro e segundo instares de Argas (Persicargas) miniatus quando submetidas a diferentes períodos de jejum (15, 30 e 60 dias), foram estudados em estufa climatizada $\left(27 \pm 1^{\circ} \mathrm{C}\right.$ e $80 \pm 10 \%$ de umidade relativa) e em ambiente de laboratório. Ninfas de primeiro instar que foram submetidas a um período de jejum de 15 e 30 dias mudaram para ninfas de segundo e terceiro instar, em ambas as condiçóes estudadas. No período de 60 dias de jejum verificou-se mortalidade de 28 e $37 \%$ das ninfas de primeiro instar, em estufa climatizada e em ambiente de laboratório, respectivamente. As ninfas sobreviventes náo se fixaram sobre os hospedeiros. As ninfas de segundo instar, após 60 dias de jejum, desenvolveram-se em ninfas de terceiro instar ou machos, quando alimentadas em Gallus gallus. Ainda neste grupo, as ninfas de terceiro instar mudaram para adultos (42,42 e 40,54\% machos; 36,36 e 48,65\% fêmeas, nas condições ambiente de laboratório e estufa climatizada, respectivamente) e o restante desenvolveu-se em ninfas de quarto instar que por sua vez mudaram para fêmeas. Entáo, a situaçáo de jejum (60 dias) em que as ninfas foram submetidas determinou o número de ninfas no ciclo biológico de $A$. miniatus, sob as condiçóes experimentais estudadas.

Palavras-chave: Argas (Persicargas) miniatus, número de instares ninfais, período de jejum, argasídeo.

\footnotetext{
${ }^{*}$ Corresponding author: Huarrisson Azevedo Santos

Curso de Pós-Graduação em Ciências Veterinárias,

Universidade Federal Rural do Rio de Janeiro - UFRRJ,

BR 465, Km 7, CEP 23890-000, Seropédica - RJ, Brazil;

e-mail: huarrisson@yahoo.com.br;
} 


\section{Introduction}

The Argas (Persicargas) miniatus Koch, 1844 (Acari: Argasidae) is the only species of the genus Argas occurring in Brazil. Its natural host is the Gallus gallus. In the wild, this tick is found mainly in small domestic breeds of $G$. gallus, where they may cause losses in productivity due to blood feeding, transmission of pathogens such as Borrelia anserina (MARCHOUX; SALIMBENI, 1903; LISBOA, 2006) and paralysis induced by larvae in young birds (GOTHE et al., 1979; MAGALHÂES et al., 1987). The severity of paralysis depends on the amount of neurotoxin released in the bird tissues, which occurs mostly in the final phase of larvae ingurgitation (MANS et al., 2004).

Different biotic and abiotic factors act on the life cycle of Argasidae. The abiotic factors have direct effects on the free-living phases and may extend or shorten the life cycle. The number of nymphal instars in the ticks of the Argasidae is affected by climatic changes, the volume of ingested blood, and the type of host (BALASHOV, 1968; ISAAC, 1977). The main factor affecting the number of nymphal instars is the volume of ingested blood (BALASHOV, 1968). According to Isaac (1977), the amount of blood ingested, which in turn indirectly affects the number of nymphal instars, may be determined by the fixation site and the temperature and light intensity occurring while the ticks of the Argas are feeding on the host.

In Brazil, the data about the biology of this tick species are limited to the published studies by Rohr (1909), Magalhães (1979), Schumaker and Oba (1988), and Santos (2009). None of these authors investigated the effect of the fasting period of nymphs of the first and second instars on the number of the following instars and on the sex ratio of $A$. miniatus, the aim of the present study.

\section{Material and Methods}

\section{Study site}

This study was carried out at the Estação Experimental para Pesquisas Parasitológicas Wilhelm Otto Neitz do Departamento de Parasitologia Animal, Instituto de Veterinária da Universidade Federal Rural do Rio de Janeiro (UFRRJ).

\section{Origin and maintenance of hosts}

Adult birds, G. gallus, of the Rhode Island Red breed, acquired in commercial flocks were feed on concentrated commercial ration and given water ad libitum. Birds were kept in individual cages and kept isolated.

\section{Origin and maintenance of the A. (P.) miniatus colony}

Engorged females of $A$. miniatus were obtained from a small chicken breeds from a farm on Lago Norte, Brasília, Federal District (FD) $\left(15^{\circ} 46^{\prime} \mathrm{S}\right.$ and $\left.47^{\circ} 55^{\prime} \mathrm{W}\right)$. The studied sample was denominated Argas (Persicargas) miniatus Brasília-FD sample, due to its origin.

Eggs from A. miniatus females were separated and transferred into $5 \mathrm{~mL}$ plastic syringes plugged with cotton and incubated in acclimatized chambers such as "Biochemical Oxygen Demand" (B.O.D.) at $27 \pm 1{ }^{\circ} \mathrm{C}$, relative humidity (RH) of $80 \pm 10 \%$ and scotophase, for observation of the beginning of the larval eclosion.

\section{Infestation in Gallus gallus and experimental groups}

Nymphs of the first instar that originated from larvae that ecloded on the same day were individually weighed and included in one of two groups of similar weight. These were kept in a B.O.D. at $27 \pm 1{ }^{\circ} \mathrm{C}$ and $80 \pm 10 \%$ relative humidity (RH) and in room conditions that varied between 16.3 and $30.2^{\circ} \mathrm{C}$, during the period of between March and June of 2005. In each case we studied 300 nymphs of the first instar. In each experimental condition, nymphs of the first instar that molted on the same day were further separated in three groups of 100 specimens each. Each group was submitted to 15 (T15), 30 (T30) and 60 days (T60) of fasting. The fasting period was that considered between eclosion and the next meal. The T15 group was used as control, as this fasting time is ideal for maintaining this tick species in the laboratory (SANTOS, 2009). After the fasting periods of 15, 30 and 60 days, nymphal instars were allowed to feed on the inner side of an adult bird wing, manually restrained for this purpose, and according to Kaiser (1966).

The following biological parameters were evaluated: engorgement time (time elapsed since the moment of attaching on the host skin until detachment), weight before and after blood feeding, engorgement level (difference between the weight before feeding and the weight after being fed and after coxal liquid release), average period of molting in days (time elapsed since feeding day until eclosion day) (Table 1) and percentage of molting and the sex ratio originated from each nymphal instar (Table 2).

\section{Statistical analysis}

The biological aspects of the nymphal stage of Argas miniatus (weight before feeding, weight after feeding, feeding time and molting period) were statistically evaluated by non-parametrical variance analysis using the Kruskal-Wallis test, with the treatments of 15,30 and 60 days of fasting evaluated separately under environmental conditions and B.O.D. $\left(27 \pm 1.0{ }^{\circ} \mathrm{C}\right.$ and $\mathrm{RH}$ of $80 \pm 10 \%$ ). When significant, the average of the fasting periods were compared using the $t$-Student test in which an error lower than 5\% was considered, according to Conover (1999).

\section{Results and Discussion}

The average before-feeding weight of nymphs of the first (N1), second (N2) and third (N3) instars in the T15 group, kept in the B.O.D., was higher $(\mathrm{p}<0.05)$ than the average of nymphs in the T30 group, but not different than that in the T60 group ( $p>0.05)$. 
These same results were observed for N1 and N3 nymphs in the environmental condition but fasting did not affect the average weight of N2 nymphs (Table 1). We observed that prolonged fasting affects the weight of nymphal instars of $A$. (P.) miniatus, especially in the first 30 days, most likely because during this period ticks present a higher level of excretion, contributing to the decrease in weight. It is noteworthy that until now there are no studies that discuss how fasting affects the weight of $A$. (P.) miniatus.

The average molting time of nymphs kept in the B.O.D.in the T30 group was higher than that in the T15 group $(p<0.05)$. Nevertheless, the average molting time did not differ $(p>0.05)$ among nymphs in groups T30 and T60. The isolated effect of fasting on the molting period of the nymphs under room conditions could not be evaluated, as this biological aspect highly depends on abiotic factors such as temperature and humidity (ROHR, 1909; SCHUMAKER; OBA, 1988). We observed that the molting period of the nymphs of $A$. (P.) miniatus was more affected by environmental conditions they were exposed to (room conditions and B.O.D.) than by the fasting period (Table 1).

Nymphs $\mathrm{N}_{1}$ of groups T15 and T30, kept in the B.O.D. and room conditions developed into $\mathrm{N}_{2}$ and $\mathrm{N}_{3}$ nymphs. We observed a mortality ratio of 28 and $37 \%$ in nymphs of the group T60 when kept in the B.O.D. and in room conditions, respectively. The remaining survivors were not able to attach on the host (Table 2). Thus, 44 (approximately half of the number of nymphs) $\mathrm{N}_{2}$ from the T30 group kept under room conditions and 48 nymphs kept in the B.O.D. were submitted to 60 days of fasting (Table 3).
The $\mathrm{N}_{2}$ nymphs submitted to this fasting period developed into $\mathrm{N}_{3}$ and males, in both experimental conditions applied in this study. Part of the $\mathrm{N}_{3}$ developed into nymphs of the fourth instar $\left(\mathrm{N}_{4}\right)$ and into adults in which 42.42 and $40.54 \%$ were males under room conditions and acclimatized oven, respectively, and 36.36 and $48.65 \%$ were females, under the same conditions as males. All $\mathrm{N}_{4}$ developed into females in both experimental conditions (Table 3). Noteworthy is the fact that the appearance of $\mathrm{N}_{4}$ in the life cycle of $A$. miniatus is a rare event observed only when ticks are submitted to 60 days of fasting.

Under the experimental conditions of this study, the fasting period affected the number of nymph instars of $A$. (P.) miniatus. We observed that a higher number of $\mathrm{N}_{3}$ in the $\mathrm{T} 60$ group, under room conditions, developed into $\mathrm{N}_{4}$ (Table 3). This fact most likely is related with the environment stress this species undergoes in this condition. According to Balashov (1968), the number of nymphal instars in species of Argasidae is genetically controlled, and species and sub-species of the Argas have a characteristic number of nymphal instars. Genetic plasticity, however, may allow variations of this number depending on environmental conditions. According to the author, temperature and blood meal affect the number of nymphal instars of $A$. (P.) persicus Oken (1818), Ornithodoros papillipes Birula (1895) and O. tartakovsky Olenev (1931). The O. papillipes usually has between three and four nymphal instars, but when one of them does not completely engorge, an additional instar originates. The same occurs with A. (P.) arboreus (HAFEZ et al., 1971). Isaac (1977) verified that

Table 1. Average values and standard deviation of the weight (before and after feeding), feeding duration, and molting of nymphal instars of Argas (Persicargas) miniatus, kept in room environment and in an B.O.D. (27 $\pm 1.0^{\circ} \mathrm{C}$ and $80 \pm 10 \%$ RH), under different fasting periods.

\begin{tabular}{|c|c|c|c|c|c|c|}
\hline Nymphal instar & $\begin{array}{c}\text { Experimental } \\
\text { condition }\end{array}$ & $\begin{array}{c}\text { Fasting period } \\
\text { (days) }\end{array}$ & $\begin{array}{l}\text { Weight before } \\
\text { feeding (mg) }\end{array}$ & $\begin{array}{l}\text { Weight after } \\
\text { feeding }(\mathrm{mg})\end{array}$ & $\begin{array}{c}\text { Feeding duration } \\
\text { (minutes) }\end{array}$ & $\begin{array}{c}\text { Molting } \\
\text { (days) }\end{array}$ \\
\hline \multirow[t]{6}{*}{ Nymph 1} & Room & 15 & $0.53 \pm 0.08^{\mathrm{B}}$ & $2.26 \pm 0.31^{\mathrm{A}}$ & $19.16 \pm 7.2^{\mathrm{A}}$ & $8.78 \pm 2.4^{\mathrm{A}}$ \\
\hline & & 30 & $0.57 \pm 0.09^{\mathrm{A}}$ & $2.20 \pm 0.4^{\mathrm{A}}$ & $19.49 \pm 8.3^{\mathrm{A}}$ & $6.76 \pm 1.1^{\mathrm{B}}$ \\
\hline & & 60 & - & - & - & - \\
\hline & B.O.D. & 15 & $0.58 \pm 0.11^{\mathrm{a}}$ & $2.35 \pm 0.39^{\mathrm{a}}$ & $17.98 \pm 6.6^{\mathrm{a}}$ & $7.68 \pm 1.14^{\mathrm{a}}$ \\
\hline & & 30 & $0.54 \pm 0.08^{b}$ & $2.05 \pm 0.46^{\mathrm{b}}$ & $17.96 \pm 5.88^{\mathrm{a}}$ & $8.31 \pm 1.27^{\mathrm{b}}$ \\
\hline & & 60 & - & - & - & - \\
\hline \multirow[t]{6}{*}{ Nymph 2} & Room & 15 & $2.28 \pm 0.39^{\mathrm{A}}$ & $5.32 \pm 1.04^{\mathrm{A}}$ & $18.38 \pm 7.27^{\mathrm{A}}$ & $7.77 \pm 1.14^{\mathrm{C}}$ \\
\hline & & 30 & $2.29 \pm 0.55^{\mathrm{A}}$ & $5.56 \pm 1.32^{\mathrm{A}}$ & $20.77 \pm 8.56^{\mathrm{A}}$ & $11.31 \pm 2.04^{\mathrm{B}}$ \\
\hline & & 60 & $2.19 \pm 0.48^{\mathrm{A}}$ & $5.19 \pm 1.12^{\mathrm{A}}$ & $17.11 \pm 6.21^{\mathrm{A}}$ & $15.70 \pm 4.13^{\mathrm{A}}$ \\
\hline & B.O.D. & 15 & $2.54 \pm 0.49^{\mathrm{a}}$ & $5.87 \pm 1.28^{\mathrm{a}}$ & $17.77 \pm 6.76^{a}$ & $7.86 \pm 0.94^{\mathrm{b}}$ \\
\hline & & 30 & $2.24 \pm 0.55^{\mathrm{b}}$ & $5.30 \pm 1.0^{\mathrm{b}}$ & $15.81 \pm 6.89^{\mathrm{a}}$ & $8.53 \pm 0.95^{a}$ \\
\hline & & 60 & $2.11 \pm 0.55^{\mathrm{b}}$ & $4.94 \pm 0.98^{\mathrm{b}}$ & $16.96 \pm 5.88^{\mathrm{a}}$ & $8.50 \pm 0.77^{a}$ \\
\hline \multirow[t]{6}{*}{ Nymph 3} & Room & 15 & $3.91 \pm 1.40^{\mathrm{A}}$ & $14.45 \pm 5.75^{\mathrm{A}}$ & $13.57 \pm 2.99^{\mathrm{B}}$ & $11.36 \pm 2.49^{\mathrm{B}}$ \\
\hline & & 30 & $3.77 \pm 1.52^{\mathrm{B}}$ & $14.42 \pm 4.42^{\mathrm{A}}$ & $16.83 \pm 6.77^{\mathrm{B}}$ & $17.69 \pm 4.71^{\mathrm{A}}$ \\
\hline & & 60 & $3.63 \pm 1.29^{\mathrm{B}}$ & $15.04 \pm 4.82^{\mathrm{A}}$ & $21.12 \pm 6.32^{\mathrm{A}}$ & $19.42 \pm 5.01^{\mathrm{A}}$ \\
\hline & B.O.D. & 15 & $4.01 \pm 1.35^{\mathrm{a}}$ & $15.66 \pm 5.60^{\mathrm{a}}$ & $11.41 \pm 2.11^{\mathrm{c}}$ & $9.94 \pm 1.45^{b}$ \\
\hline & & 30 & $3.66 \pm 1.48^{b}$ & $14.06 \pm 4.24^{\mathrm{a}}$ & $16.32 \pm 5.42^{\mathrm{b}}$ & $10.31 \pm 0.59^{\mathrm{a}}$ \\
\hline & & 60 & $3.41 \pm 1.12^{\mathrm{b}}$ & $14.30 \pm 4.18^{\mathrm{a}}$ & $19.08 \pm 8.03^{\mathrm{a}}$ & $10.41 \pm 0.60^{\mathrm{a}}$ \\
\hline \multirow[t]{2}{*}{ Nymph 4} & Room & 60 & $7.07 \pm 1.01$ & $25.39 \pm 2.35$ & $15.86 \pm 3.76$ & $14.86 \pm 0.90$ \\
\hline & B.O.D. & 60 & $7.03 \pm 0.51$ & $24.85 \pm 1.18$ & $17.25 \pm 3.50$ & $8.75 \pm 0.50$ \\
\hline
\end{tabular}

${ }^{a}$ Values in columns followed by small capital and similar letters, for each nymphal instar, do not differ according to the $t$-Student a $\mathrm{p}<0.05$ (results refer to B.O.D.); ${ }^{A}$ Values in columns followed by capital and similar letters, for each nymphal instar, do not differ according to the $t$-Student a $\mathrm{p}<0.05$ (results refer to room conditions). 
Table 2. Dynamics of the molting of nymphal instars (N1-3) and male/female ratio of Argas (Persicargas) miniatus kept in room conditions and in an B.O.D. $\left(27 \pm 1.0^{\circ} \mathrm{C}\right.$ and $\left.80 \pm 10 \% \mathrm{RH}\right)$, under different fasting periods.

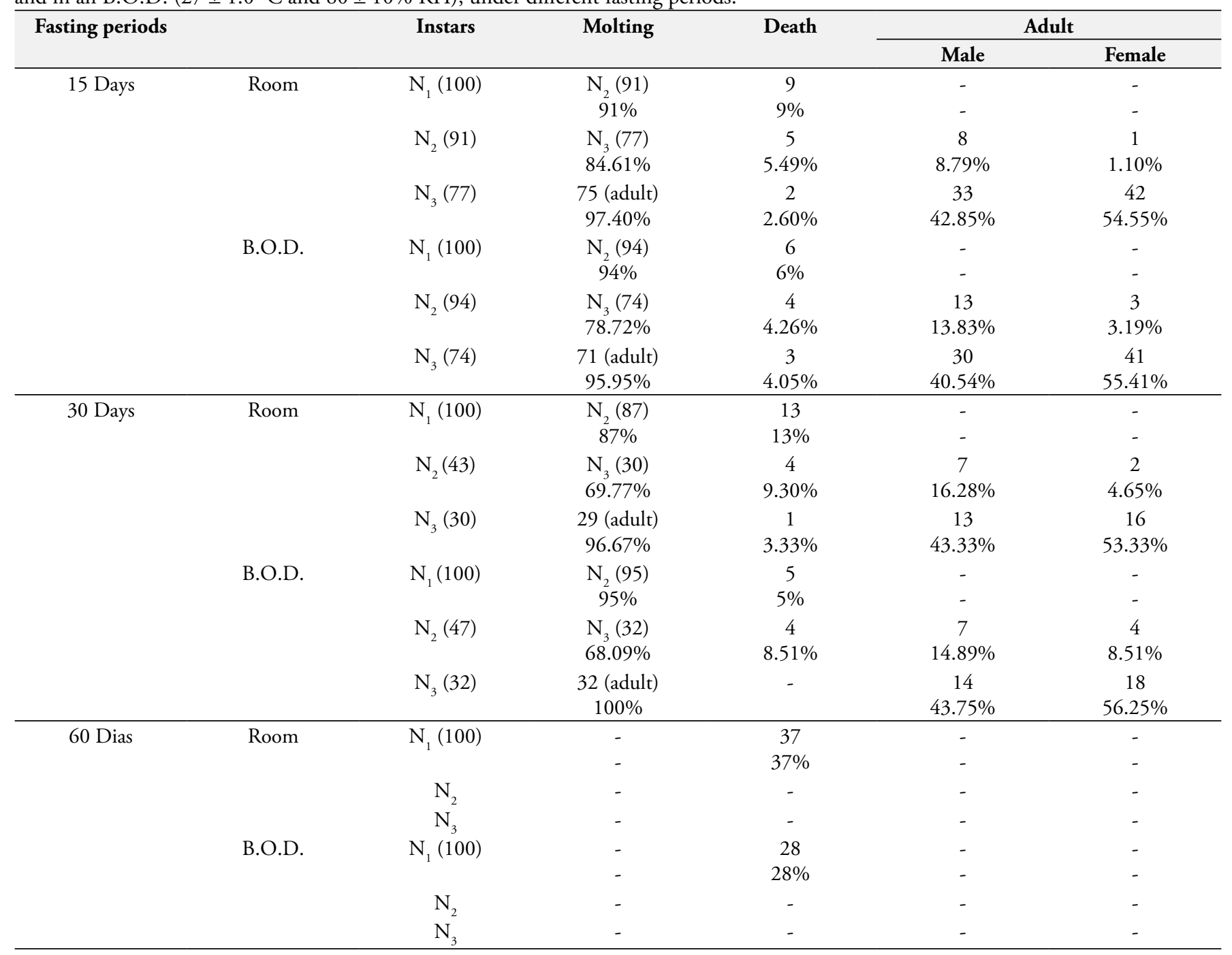

Table 3. Dynamics of the molting of the second nymphal instar $\left(\mathrm{N}_{2}\right)$ and male/female ratio of Argas (Persicargas) miniatus (sample from Brasília-FD) kept in room conditions and in an B.O.D. $\left(27 \pm 1.0^{\circ} \mathrm{C}\right.$ and $\left.80 \pm 10 \% \mathrm{RH}\right)$ under 60 day fasting.

\begin{tabular}{|c|c|c|c|c|c|c|}
\hline & & \multirow[t]{2}{*}{ Instars } & \multirow[t]{2}{*}{ Molting } & \multirow[t]{2}{*}{ Death } & \multicolumn{2}{|c|}{ Adult } \\
\hline & & & & & Male & Female \\
\hline \multirow{9}{*}{60 Days } & \multirow{4}{*}{ Room } & $\mathrm{N}_{2}(44)$ & $\mathrm{N}_{3}(33)$ & 4 & 7 & \\
\hline & & & $75 \%$ & $9.09 \%$ & $15.91 \%$ & - \\
\hline & & $\mathrm{N}_{3}(33)$ & $\mathrm{N}_{4}(7)$ & - & 14 & 12 \\
\hline & & & $21.21 \%$ & & $42.42 \%$ & $36.36 \%$ \\
\hline & \multirow{5}{*}{ B.O.D. } & $\mathrm{N}_{2}(48)$ & $\mathrm{N}_{3}(37)$ & 2 & 9 & - \\
\hline & & & $77.08 \%$ & $4.17 \%$ & $18.75 \%$ & \\
\hline & & $\mathrm{N}_{3}(37)$ & $\mathrm{N}_{4}(4)$ & - & 15 & 18 \\
\hline & & & $10.81 \%$ & & $40.54 \%$ & $48.65 \%$ \\
\hline & & $\mathrm{N}_{4}(4)$ & 4 (adult) & & & 4 \\
\hline
\end{tabular}


the amount of blood ingested by this species during the nymphal period may reach a minimum threshold before ticks change to the adult stage. If the threshold is not reached the number of nymphal instars increases.

Still according to Isaac (1977), the quality or type of blood seems to have less effect on the number of nymphal instars than the amount of blood.. Nevertheless, when $A$. (P.) persicus, which feed preferentially on birds, feed on mammals, it led to an additional nymphal instar (BALASHOV, 1968). This author verified that temperature is an important factor affecting the biological aspects of ticks. Indeed, in low temperatures $\left(20^{\circ} \mathrm{C}\right)$ the number of nymphal instars of $A$. ( $P$. ) persicus changes, with the occurrence of a fourth instar, while in higher temperatures $\left(30{ }^{\circ} \mathrm{C}\right)$ the third nymphal instar practically does not occur and some males and females may directly eclode from $\mathrm{N}_{1}$. In $O$. papillipes, on the other hand, high temperatures $\left(30{ }^{\circ} \mathrm{C}\right)$ determine the opposite effect, increasing the number of nymphal instars (BALASHOV, 1963).

Apparently, each species of Argasidae has a set of optimal conditions for its development, in which environmental temperature, amount of food and relative air humidity stand out. In this study we observed a greater amount of nymphs $\left(\mathrm{N}_{4}\right)$ under room conditions. This finding suggests that besides fasting, variations in humidity and environmental temperature may also play a role on the number of nymph instars of $A$. (P.) miniatus (Table 3 ).

\section{Conclusions}

The $\mathrm{N}_{1}$ nymphs of $A$. miniatus that survived the 60 -day fasting were not able to attach to the host. The $\mathrm{N}_{2}$ nymphs submitted to the 60-day fasting originated from $\mathrm{N}_{3}$ and males; while the $\mathrm{N}_{3}$ developed into $\mathrm{N}_{4}$, from which only females originate. The addition of the $\mathrm{N}_{4}$ in the life cycle of $A$. miniatus takes place only when $\mathrm{N}_{3}$ are kept for 60-day fasting, in both experimental conditions here studied. Thus, the fasting period may affect not only survival of nymphs but also the number of nymphal instars and even the sex ratio.

\section{References}

BALASHOV, Y. S. The effetc of external factors on the number of nymphal instars in argasid Ticks. Paratitology Sb. Zoological Institute of Akademii Nauk SSSR, v. 21, n. 1, p. 28-38, 1963.

BALASHOV, Y. S. A translation of bloodsucking ticks (Ixodoidea) Vectors of diseases of man and animals. 1968. 376 p.
CONOVER, W. J. Practical nonparametrics statistics. 3 ed. New York: John Wiley \& Sons, 1999. 592 p.

GOTHE, R.; KUNZE, K.; HOOGSTRAAL, H. The mechanisms of pathogenicity in the tick paralyses. Journal of Medical Entomology, v. 16 , n. 5 , p. 357-369, 1979.

HAFEZ, M.; ABDEL-MALEK, A. A.; GUIRGIS, S. S. The subgenus Persicargas (Ixodoidea, Argasidae, Argas). 12. Biological studies on the imature stages of $A$. (P.) arboreus Kaiser, Hoogstraal \& Kohls in Egypt. Journal of Medical Entomology, v. 8, n. 4, p. 421-429, 1971.

ISAAC, I. S. The subgenus Persicargas (Ixodoidea, Argasidae, Argas). 28. Argas (P.) arboreus: Effect of blood meal weight on nymphal instar numbers. Journal of Medical Entomology, v. 13, n. 4-5, p. 609-611, 1977.

KAISER, M. N. The subgenus Persicargas (Ixodoidea, Argasidae, Argas). 3. The life cycle of $A$. (P.) arboreus, and a standardized rearing method for Argasid ticks. Annals of the Entomological Society of America, v. 59, n. 3, p. 496-502, 1966.

LISBOA, R. S. Estudo da transmissáo experimental de Borrelia anserina (Sakharoff, 1891) por Argas (Persicargas) miniatus Kock, 1844 e avaliaçáo comparative de parâmetros clínicos e hematológicos em Gallus gallus Linnaeus, 1758. 2006. 63 f. Dissertação (Mestrado)Universidade Federal Rural do Rio de Janeiro, Seropédica.

MAGALHÃES, F. E. P. Novos aspectos morfológicos, biológicos e tóxicos de Argas (Persicargas) miniatus Koch, 1844 (Ixodoidea, Argasidae) no Estado do Rio de Janeiro. 1979. 95 f. Dissertação (Mestrado)-Universidade Federal Rural do Rio de Janeiro, Seropédica, 1979.

MAGALHÃES, F. E. P.; MASSARD, C. L.; SERRA-FREIRE, N. M. Paralysis in Gallus gallus and Carina moschata induced by larvae of Argas (Persicargas) miniatus. Pesquisa Veterinária Brasileira, v. 7. n. 2, p. $47-49,1987$.

MANS, B. J.; GOTHE, R.; NEITZ, W. H. Biochemical perspectives on paralysis and other forms of toxicoses caused by ticks. Parasitology, v. 129 , n. 2, p. 95-111, 2004.

MARCHOUX, E.; SALIMBENI, A. La spirillose des poules. Annales de I'Institut Pasteur Lille, v. 17, n. 1, p. 569-580, 1903.

ROHR, C. J. Estudo sobre ixodidas do Brasil. Rio de Janeiro: Gomes, Irmão \& C., 1909. 226 p.

SANTOS, H. A. Ciclo biológico comparado de Argas (Persicargas) miniatus Koch, 1844 (Acari: Argasidae) alimentados em Gallus gallus. 2009. 52 f. Dissertação (Mestrado) - Universidade Federal Rural do Rio de Janeiro, Seropédica, 2009.

SCHUMAKER, T. T. S.; OBA, M. S. P. Aspectos Morfo-biológicos de Argas (Persicargas) miniatus. Koch, 1844 (Ixodoidea, Argasidae). Revista Brasileira de Entomologia, v. 32, n. 2, p. 161-173, 1988. 